\section{Aa@}

Autobiografia $\mathrm{nr} 2$ (13) 2019 s. 41-42

ISSN 2353-8694

DOI: 10.18276/au.2019.2.13-04

TEORIE

\title{
Biogram Sándora Ferencziego
}

Sándor Aleksander Ferenczi urodził się w 1873 roku w Miszkolcu w rodzinie polskich Żydów. Jego rodzice, Baruch i Rosa Fränkel, pochodzili z Krakowa. Studia medyczne przyszły psychoanalityk odbył w Wiedniu. Dyplom tamtejszego Uniwersytetu Medycznego w zakresie neurologii i psychiatrii otrzymał w 1896 roku. Od 1897 roku praktykował w szpitalach w Budapeszcie, gdzie w 1900 roku otworzył prywatny gabinet. W tym czasie był również związany z czasopismem medycznym „Gyógyàszat” prowadzonym przez Miksę Schächtera. O teorii psychoanalitycznej po raz pierwszy dowiedział się od przyjaciela Filipa Steina, który w 1907 roku przekazał mu egzemplarz Objaśniania marzeń sennych. Do pierwszego spotkania z twórcą psychoanalizy doszło dzięki inicjatywie Carla Gustava Junga, z którym Ferenczi przybył do Wiednia w 1908 roku. W 1910 roku Ferenczi zainicjował powstanie Międzynarodowego Towarzystwa Psychoanalitycznego, którego prezesem pozostawał od 1918 roku do 1919 roku. W 1913 roku utworzył Węgierskie Towarzystwo Psychoanalityczne, któremu przewodniczył przez kolejne dwie dekady. Dążenia Ferencziego do zaszczepienia myśli Freuda na Węgrzech początkowo odniosły lepsze skutki w środowisku literackim niż medycznym. Od 1908 roku psychoanalityk współpracował z pisarzami modernistycznymi zebranymi wokół czasopisma literackiego „Nyugat”. W okresie 1917-1919 lekarz zajmował się studiowaniem neuroz wojennych. W latach 1920-1926 poświęcił się natomiast rozwijaniu psychoanalitycznej techniki pracy z pacjentami, czego efektem były artykuły „Weiterer Ausbau der «aktiven Technik» in der Psychoanalyse” (Internationale Zeitschrift für Psychoanalyse 7, 1921, 3: 233-251) i „Kontraindikationen der aktiven psychoanalytischen Technik” (Internationale Zeitschrift für Psychoanalyse 12, 1926, 1:3-14), a także rozprawa Entwicklungsziele der Psychoanalyse (Leipzig: Internationaler Psychoanalytischer Verlag, 1924) napisana wspólnie z Ottonem Rankiem. W tym samym roku Ferenczi opublikował kolejne dzieło pt. Versuch einer Genitaltheorie (Wien: IPV, 1924) często uważane za jego najważniejszą rozprawę. Na przełomie 1926 i 1927 roku analityk przebywał w Stanach Zjednoczonych, gdzie na zaproszenie New York Society of Clinical Psychiatry oraz American Psychoanalytic Association prowadził gościnne wykłady. Na 
początku lat 30. XX wieku kontakty z Freudem oraz Wiedeńskim Towarzystwem Psychoanalitycznym uległy ochłodzeniu, co wpłynęło na postępującą alienację węgierskich freudystów. W 1932 roku Ferenczi wziął jeszcze udział w XII Kongresie Psychoanalitycznym w Wiesbaden, gdzie wygłosił odczyt pod tytułem „Sprachverwirrung zwischen den Erwachsenen und dem Kind” (Internationale Zeitschrift für Psychoanalyse 9, 1932, 1-2: 5-15). Dowodził w nim, że dziecko nie posiada erotycznych pragnień sensu stricto, lecz oczekuje jedynie miłości i ciepła od opiekunów. Według analityka tylko dorośli mogą projektować na potomstwo własne pragnienia i fantazje. Ferenczi zakwestionował tym samym seksualność infantylną, w formie proponowanej przez Freuda. Starał się też wskazać na realny, nie zaś fantazmatyczny wymiar traum dziecięcych. Tekst ten wyznacza moment definitywnego odejścia od klasycznej psychoanalizy freudowskiej. Między styczniem a listopadem 1932 roku analityk prowadził dziennik kliniczny, opublikowany po jego śmierci, pod tytułem Das Klinische Tagebuch (Gießen: Psychosozial-Verlag, 2013), w którym wprowadził koncepcję terapii psychoanalitycznej jako „wzajemnej analizy” (Mutuelle Analyse) oraz poddał krytyce podstawowe założenia teorii Freudowskiej. Ferenczi zmarł w Budapeszcie w 1933 roku. 